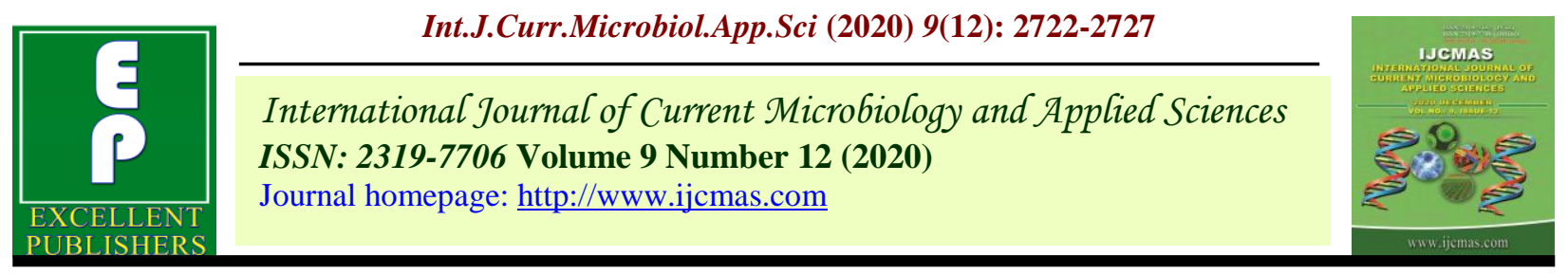

Original Research Article

https://doi.org/10.20546/ijcmas.2020.912.323

\title{
Evaluation of Kharif Onion (Allium cepa L.) Varieties in Malwa Agro Climatic Zone of Madhya Pradesh
}

\author{
Nishith Gupta*, K. S. Bhargav and A. K. Dixit \\ R.V.S.K.V.V. Krishi Vigyan Kendra, Dewas, Madhya Pradesh, India \\ *Corresponding author
}

\section{A B S T R A C T}

\section{Ke y w ords \\ On farm testing, Kharif onion, Bhima Dark Red, Agrifound Dark Red, N-53, Yield, Cured weight \\ Article Info \\ Accepted: \\ 18 November 2020 Available Online: 10 December 2020}

The on farm testing was conducted in the farmers' fields of Dewas district of Madhya Pradesh with the objective to find out the most suitable varieties of kharif onion for two consecutive years i.e. 2018-19 and 2019-20. From the study it is revealed that onion variety Bhima Dark Red performed better in growth, yield, yield attributing parameters and economic returns as compared to Agrifound Dark Red and N-53 varieties. Maximum plant height $(58.37 \mathrm{~cm})$, number of leaves per plant $(12.29)$, leaf length $(52.18 \mathrm{~cm})$, bulb diameter $(6.04 \mathrm{~cm})$, fresh weight of bulb $(103.10 \mathrm{~g})$, cured weight of bulb $(90.84 \mathrm{~g})$, bulb yield $(219.55 \mathrm{q} / \mathrm{ha})$ and minimum neck thickness of bulb $(1.10 \mathrm{~cm})$ and bolting percentage $(0.55 \%)$ were found in Bhima Dark Red.Bhima Dark Red variety recorded additional net returns of Rs. 53,320 and Rs. 2,44,819 over Agrifound Dark Red and N-53. Highest B:C ratio was obtained with Bhima Dark Red (6.57) as compared to Agrifound Dark Red (5.99) and N-53 (3.03).

\section{Introduction}

Onion (Allium cepa L.) is an important bulb crop of India, which is extensively cultivated throughout India for its high nutritional and medicinal properties. It is also called as "Queen of Kitchen" (Selviraj, 1976) and is widely used as salad, cooked in curries, boiled, fried, baked and picked. Onion is stimulant, diuretic and having expectorant and antibacterial properties. It prevents heart disease by lowering blood cholesterol and lipid level (Sharangi and Datta, 2005). With a production of 23.26 million metric tons of onion from 1284.99 thousand ha area in 2017-
18 , India is the second largest onion producer in the World after China. In India, the share of Maharashtra in the total onion production is around $38.06 \%$ in contrast to Madhya Pradesh contributing only $15.91 \%$ (Horticultural Statistics at a Glance-2018, Department of Agriculture, Cooperation \& Farmers Welfare, 2018). The production seasons and arrivals of onion in India lead to a typical situation where in the prices tend to peak during September to November and reduces from January to March-April every year. Generally the onion storage filled by Rabi onion gets emptied by around August to September beyond which storage loss rises to $30 \%$ and 
above (Samra et al., 2006). Production of onion in kharif and late kharif season is beneficial for farmer's point of view to get maximum price as compared to rabi onion. Kharif onion is an off-season cultivation of the crop for which standardization of varieties is of immense utility. Unfortunately there is limited varietal wealth for Kharif and late Kharif. As a result, few varieties are being grown to some extent, but scientific information is not available on their performance on growth and yield.

Dewas district which comes under the Malwa agro climatic zone of Madhya Pradesh is an important onion growing district but the major area under onion cultivation in the district is during rabi season and area under kharif onion cultivation is negligible. During the Participatory Rural Appraisal (PRA) survey, farmers and scientists comes to the conclusion that there is a vast scope of onion cultivation in kharif season which will be more profitable over traditional crop soybean. Hence, in this regard, the present on farm testing study was undertaken with the objective to explore the possibility of cultivation of this crop and to assess the suitable kharif onion varieties in different locations in Dewas district through farmer's participatory approach.

\section{Materials and Methods}

The present study was carried out by the Krishi Vigyan Kendra, Dewas during Kharif season of 2018-19 and 2019-20 in the farmers' fields of adopted villages of operational area of KVK. Two improved varieties viz. Agrifound Dark Red and Bhima Dark Red along with one check variety i.e. N53 were evaluated in an area of 0.3 ha.

Seeds of each variety were sown in line on well levelled raised beds in the month of May every year and healthy seedlings of 45 days old were transplanted in the field after cutting upper $1 / 3$ portions of leaves to reduce the loss of water through transpiration. Soil of the study area is light to medium black in texture with low organic carbon, low nitrogen, medium phosphorus and high in available potassium. All the recommended package of practice was adopted in all the entries uniformly to raise a good crop.

The crop was fertilized with recommended dose of 100:50:50:40 Kg NPKS and $5 \mathrm{~kg}$ zinc per hectare as recommended by ICARDirectorate of Onion and Garlic Research, Rajgurunagar, Pune. 50\% $\mathrm{N}_{2}$ and $100 \% \mathrm{P}_{2} \mathrm{O}_{5}$, $\mathrm{K}_{2} \mathrm{O}, \mathrm{S}$ and $\mathrm{ZnSo}_{4}$ were added as basal dose and remaining $50 \% \mathrm{~N}_{2}$ in two equal splits at an interval of 30 and 45 days after transplanting. Frequent training programmes and field visits were conducted on farmer's field by the KVK scientists during the various field operations like transplanting, weeding, intercultural operations, nutrient management, irrigation, plant protection measures and harvesting etc. All other steps like site and farmer selection, layout of demonstration, farmers participation etc were followed as suggested by Choudhary (1999).

Ten plants were randomly selected from each variety during both the years to record observations on growth, yield, quality parameters, pest and disease incidence. The bulb yield was accounted on plot bases.

Economics of onion was worked out on the basis of production cost and monetary returns. Cost of cultivation was calculated on the basis of prevailing rate of inputs. Gross income was calculated by yield multiplied with a wholesale rate of onion. The benefit cost ratio was computed by the following formula.

$$
\text { Benefit Cost Ratio }=\frac{\text { Gross Income }}{\text { Cost of Cultivation }}
$$




\section{Results and Discussion}

The results obtain from the present investigation during Kharif 2018-19 and 2019-20 are discussed given below.

\section{Growth and yield attributes}

The present investigation revealed that among the three onion varieties, profound effect was seen on growth and yield attributing parameters (Table 1). The maximum plant height $(58.37 \mathrm{~cm})$, number of leaves per plant (12.29), leaf length $(52.18 \mathrm{~cm})$, fresh weight of bulb $(103.10 \mathrm{~g})$, cured weight of bulb (90.84 g),bulb diameter $(6.04 \mathrm{~cm})$ was recorded in Bhima Dark Red variety followed by Agrifound Dark Red while check variety $\mathrm{N}-53$ observed minimum growth and yield attributing parameters. In onion for better keeping quality, the cultivar should have minimum neck thickness, a desirable parameter. In the present study, significantly lowest neck thickness was observed in Bhima Dark Red $(1.10 \mathrm{~cm})$ than rest of the cultivars. Besides this Bhima Dark Red observed minimum bolting percentage $(0.55 \%)$ while check variety $\mathrm{N}-53$ recorded maximum $(1.51 \%)$ bolting percentage. These differences in different growth and yield attributing parameters of onion might be due to genetic makeup of variety and suitability under different climatic and soil condition. These findings are in accordance with the findings of Mohanty and Prusti (2001), Dwivediet al., (2012), Kushal et al., (2015), Hirave et al., (2015) and Sarkar et al., (2015) in onion. The higher bulb yield was observed in Bhima Dark Red variety $(219.55 \mathrm{q} / \mathrm{ha})$ followed by Agrifound Dark Red (190.37 q/ha) and N-53 (185.33 q/ha) varieties (Table 2). 'A' and 'B' grade onion yield $(100.55 \mathrm{q} / \mathrm{ha}$ and 78.05 q/ha) was observed highest in Bhima Dark Red, while ' $C$ ' and ' $D$ ' grade (42.49 q/ha and $17.22 \mathrm{q} / \mathrm{ha}$ ) in N-53. Such superior yield of Bhima Dark Red variety was mainly due to higher growth and yield parameters like plant height, number of leaves per plant and bulb weight (fresh and cured) because bulb weight is ultimately governed by the accumulation of carbohydrates and other metabolites which depend ultimately on the synthesis and supply of photosynthates by leaves or subsequent translocation vertically downward to bulb and root as reported by Lawande et al., (2011), Tripathy et al., (2013) and Hiremath and Mantur(2018).

Table.1 Growth and yield attributing parameters of onion as influenced by different varieties

\begin{tabular}{|l|c|c|c|c|c|c|c|c|c|}
\hline \multirow{2}{*}{ Parameters } & \multicolumn{3}{|c|}{ N-53 } & \multicolumn{3}{c|}{ Agrifound Dark Red } & \multicolumn{3}{c|}{ Bhima Dark Red } \\
\cline { 2 - 11 } & $\mathbf{2 0 1 8 - 1 9}$ & $\mathbf{2 0 1 9 - 2 0}$ & Mean & $\mathbf{2 0 1 8 - 1 9}$ & $\mathbf{2 0 1 9 - 2 0}$ & Mean & $\mathbf{2 0 1 8 - 1 9}$ & $\mathbf{2 0 1 9 - 2 0}$ & Mean \\
\hline Plant Height (cm) & 56.38 & 53.92 & 55.15 & 57.12 & 54.63 & 55.88 & 58.09 & 58.64 & 58.37 \\
\hline No. of leaves/plant & 11.13 & 10.67 & 10.9 & 11.76 & 10.89 & 11.33 & 12.14 & 12.43 & 12.29 \\
\hline Leaf Length (cm) & 48.34 & 48.79 & 48.57 & 49.06 & 49.99 & 49.53 & 51.92 & 52.44 & 52.18 \\
\hline $\begin{array}{l}\text { Neck thickness of bulb } \\
\text { (cm) }\end{array}$ & 1.17 & 1.12 & 1.15 & 1.19 & 1.20 & 1.20 & 1.11 & 1.08 & 1.10 \\
\hline Fresh weight of bulb (g) & 81.26 & 80.53 & 80.90 & 85.78 & 87.07 & 86.43 & 102.73 & 103.46 & 103.10 \\
\hline Cured weight of bulb (g) & 72.06 & 72.14 & 72.1 & 74.18 & 75.04 & 74.61 & 89.07 & 92.61 & 90.84 \\
\hline Bolting \% & 1.49 & 1.52 & 1.51 & 1.09 & 1.17 & 1.13 & 0.61 & 0.49 & 0.55 \\
\hline Bulb Diameter (cm) & 4.74 & 4.93 & 4.84 & 5.09 & 5.17 & 5.13 & 5.99 & 6.08 & 6.04 \\
\hline Days to Harvest & 104 & 107 & 105.50 & 99 & 103 & 101.00 & 99 & 103 & 101 \\
\hline
\end{tabular}


Table. 2 Grade wise distribution of onion bulb and yield as influenced by different varieties

\begin{tabular}{|c|c|c|c|c|c|c|c|c|c|}
\hline \multirow[t]{2}{*}{ Parameters } & \multicolumn{3}{|c|}{$\mathrm{N}-53$} & \multicolumn{3}{|c|}{ Agrifound Dark Red } & \multicolumn{3}{|c|}{ Bhima Dark Red } \\
\hline & 2018-19 & 2019-20 & Mean & 2018-19 & 2019-20 & Mean & 2018-19 & 2019-20 & Mean \\
\hline \multicolumn{10}{|l|}{ Yield (q/ha) } \\
\hline Total yield (q/ha) & 192.34 & 178.92 & 185.63 & 197.68 & 183.06 & 190.37 & 229.74 & 209.35 & 219.55 \\
\hline $\begin{array}{l}\text { A Grade } \\
(>6.5 \mathrm{~cm})\end{array}$ & 74.30 & 70.39 & 72.37 & 84.09 & 74.34 & 79.15 & 106.53 & 94.69 & 100.55 \\
\hline $\begin{array}{l}\text { B Grade } \\
(5.5-6.5 \mathrm{~cm})\end{array}$ & 56.05 & 51.10 & 53.55 & 66.95 & 62.62 & 64.80 & 79.70 & 76.22 & 78.05 \\
\hline $\begin{array}{l}\text { C Grade } \\
(4.5-5.5 \mathrm{~cm})\end{array}$ & 43.47 & 41.47 & 42.49 & 30.07 & 29.42 & 29.77 & 31.06 & 25.46 & 28.19 \\
\hline $\begin{array}{l}\text { D Grade } \\
(<4.5 \mathrm{~cm})\end{array}$ & 18.52 & 15.96 & 17.22 & 16.57 & 16.68 & 16.65 & 12.45 & 12.98 & 12.76 \\
\hline \multicolumn{10}{|l|}{ Grade \% } \\
\hline $\begin{array}{l}\text { A Grade } \\
(>6.5 \mathrm{~cm})\end{array}$ & 38.63 & 39.34 & 38.99 & 42.54 & 40.61 & 41.58 & 46.37 & 45.23 & 45.80 \\
\hline $\begin{array}{l}\text { B Grade } \\
(5.5-6.5 \mathrm{~cm})\end{array}$ & 29.14 & 28.56 & 28.85 & 33.87 & 34.21 & 34.04 & 34.69 & 36.41 & 35.55 \\
\hline $\begin{array}{l}\text { C Grade } \\
(4.5-5.5 \mathrm{~cm})\end{array}$ & 22.6 & 23.18 & 22.89 & 15.21 & 16.07 & 15.64 & 13.52 & 12.16 & 12.84 \\
\hline $\begin{array}{l}\text { D Grade } \\
(<4.5 \mathrm{~cm})\end{array}$ & 9.63 & 8.92 & 9.28 & 8.38 & 9.11 & 8.75 & 5.42 & 6.2 & 5.81 \\
\hline
\end{tabular}

Table.3 Pest and disease incidence in different varieties

\begin{tabular}{|l|c|c|c|c|c|c|c|c|c|}
\hline \multirow{2}{*}{\multicolumn{1}{|c|}{ Parameters }} & \multicolumn{3}{|c|}{ N-53 } & \multicolumn{3}{c|}{ Agrifound Dark Red } & \multicolumn{3}{c|}{ Bhima Dark Red } \\
\cline { 2 - 9 } & $\mathbf{2 0 1 8 - 1 9}$ & $\mathbf{2 0 1 9 - 2 0}$ & Mean & $\mathbf{2 0 1 8 - 1 9}$ & $\mathbf{2 0 1 9 - 2 0}$ & Mean & $\mathbf{2 0 1 8 - 1 9}$ & $\mathbf{2 0 1 9 - 2 0}$ & Mean \\
\hline Thrips incidence (\%) & 17.21 & 16.55 & 16.88 & 16.75 & 15.84 & 16.30 & 16.52 & 15.26 & 15.89 \\
\hline $\begin{array}{l}\text { Incidence of purple } \\
\text { blotch disease (\%) }\end{array}$ & 33.38 & 35.12 & 34.25 & 31.02 & 31.46 & 31.24 & 28.63 & 29.27 & 28.95 \\
\hline
\end{tabular}

Table.4 Yield and economics of onion as influenced by different varieties

\begin{tabular}{|l|c|c|c|c|c|c|c|c|c|}
\hline \multicolumn{1}{|c|}{ Parameters } & \multicolumn{3}{|c|}{ N-53 } & \multicolumn{3}{|c|}{ Agrifound Dark Red } & \multicolumn{3}{|c|}{ Bhima Dark Red } \\
\hline & $\mathbf{2 0 1 8 - 1 9}$ & $\mathbf{2 0 1 9 - 2 0}$ & Mean & $\mathbf{2 0 1 8 - 1 9}$ & $\mathbf{2 0 1 9 - 2 0}$ & Mean & $\mathbf{2 0 1 8 - 1 9}$ & $\mathbf{2 0 1 9 - 2 0}$ & Mean \\
\hline $\begin{array}{l}\text { Yield } \\
\text { (q/ha) }\end{array}$ & 192.34 & 178.92 & 185.63 & 197.68 & 183.06 & 190.37 & 229.74 & 209.35 & 219.55 \\
\hline $\begin{array}{l}\text { Cost of } \\
\text { cultivation } \\
\text { (Rs/ha) }\end{array}$ & 60296 & 62483 & 61389.5 & 61497 & 63767 & 62632 & 64186 & 66971 & 65579 \\
\hline $\begin{array}{l}\text { Gross Return } \\
\text { (Rs/ha) }\end{array}$ & 192340 & 178920 & 185630 & 207564 & 549180 & 378372 & 241227 & 628050 & 434639 \\
\hline $\begin{array}{l}\text { Net Return } \\
\text { (Rs/ha) }\end{array}$ & 132044 & 116437 & 124241 & 146067 & 485413 & 315740 & 177041 & 561079 & 369060 \\
\hline B:C Ratio & 3.19 & 2.86 & 3.03 & 3.38 & 8.61 & 5.99 & 3.76 & 9.38 & 6.57 \\
\hline
\end{tabular}




\section{Grading parameters}

To get the higher profitability, grading of onion bulb was also done and bulb was categorized into four categories viz. 'A', 'B', ' $\mathrm{C}$ ' and ' $\mathrm{D}$ ' grade as shown in Table-2. Maximum 'A' and ' $\mathrm{B}$ ' grade onion bulb (45.80\% and $35.55 \%$ respectively) was found in Bhima Dark Red variety, while minimum in check variety $\mathrm{N}-53$ (38.99\% and $28.55 \%$ respectively), whereas, ' $\mathrm{C}$ ' and ' $\mathrm{D}$ ' grade onion bulb was observed maximum in $\mathrm{N}-53$ ( $22.89 \%$ and $9.28 \%$ respectively) variety as compared to other varieties.

\section{Pest and Disease incidence}

Besides these growth and yield parameters, Bhima Dark Red variety recorded the lowest pest i.e. thrips (15.89\%) and disease incidence i.e. purple leaf blotch $(28.95 \%)$ as compared to Agrifound Dark Red and N-53 variety (Table 3). Similar findings were also reported by Hiremath and Mantur (2018).

\section{Economics}

The year wise economics of onion production under on farm testing were estimated and the results have been presented in Table 4 . The economic analysis of the data over the years revealed that BhimaDark Red variety recorded higher gross returns (Rs. 4,34,639 per ha), net returns (Rs. 3,69,060 per ha) and $\mathrm{B}: \mathrm{C}$ ratio of 6.57 as compared to all other varieties.

Further by inclusion of Bhima Dark Red variety additional net returns of Rs. 53,320 and Rs. 2,44,819 over Agrifound Dark Red and $\mathrm{N}-53$ were gained suggesting its higher profitability and economic viability. A similar better economic return by cultivation of Bhima Super variety compared to other varieties was reported by Kerure et al., (2016).

\section{References}

Choudhary, B.N. (1999). Krishi Vigyan Kendra - A guide for KVK managers. Division of Agricultural Extension, ICAR, New Delhi.

Dwivedi, Y.C., Kushwah, S.S. andSengupta, S.K. (2012). Evaluation of onion varieties for growth, yield and quality traits under Agro-climatic conditions of Kymore plateau region of Madhya Pradesh, India. Agriculture Science Digest, 32 (4): 326-328

Hirave, P.S., Wagh, A.P., Alekar, A.N. and Kharde, R.P. (2015).Performance of red onion varieties in kharif season under Akola Conditions. Journal of Horticulture, 2 (2): 132-135.

Horticultural Statistics at a Glance (2018). Department of Agriculture, Cooperation \& Farmers Welfare. Ministry of Agriculture \& Farmers Welfare, Government of India, New Delhi.

Kerure, P., Chandrappa, D., Salimath, S., Rudragouda, F., Chandragouda,, S., Onkarappa and Gajendra T.H. (2016). Varietal assessment in onion for higher productivity and quality. In: 1st KVK Symposium zone VIII, held at UAS, Dharwad from 21-22, January, 2016.

Kushal, Patil, M.G., Nidagundi, J.M., Satihal, D.G., Mahadevaswamy and Venkatesh, K. (2015). Studies on performance of onion (Allium cepa L.) genotypes for agro-morphological traits during rabi season. International Journal of Tropical Agriculture, 33 (4): 28272830.

Lawande, K.E., Mahajan, Vijay, Krishna Prasad, V.S.R. and Khar, A. (2011). Bhima Super-a new red onion variety for kharif season from DOGR. National Symposium on Alliums: Current Scenario and Emerging Trends, 12-14 March, Pune, 160.

Mohanty, B.K. and Prusti, A.M. (2001). 
Performance of common onion varieties in kharif seasons. Journal of Tropical Agriculture, 39: 21-23.

Hiremath, S.M. and Mantur, S.M. (2018). Assessment of onion varieties for late Kharif. International Journal of Agricultural Sciences, 14 (1): 102-105.

Samra, J.S., Ramakrishna, Y.S., Desai, S., SubbaRao, A.V.M., Rama Rao, C.A., Reddy, Y.V.R., Rao, G.G.S.N., Victor, U.S. and Vijaya Kumar, P. (2006). Impact of excess rains on yield, market availability and prices of onion. Information Bulletin - Hyderabad: Central Research Institute for Dryland Agriculture.

Sarkar, R.K., Khagra, B.D., Pandit, T.K., Thapa, A.D. and Moktan, M.W. (2015). Evaluation of onion (Allium cepa L.) varieties for growth yield and quality traits under Hill Agro-climatic conditions of West Bengal. Environment and Ecology, 33 (2A): 956- 959.

Selviraj, S. (1976). Onion: Queen of the kitchen. Kisan World, 3 (12): 32-34.

Sharangi, A.B. and Datta, S. (2005). Medicinal properties of spices. Indian Journal of Arecanut, Spices and Medicinal plants, 7 (2): 42-49.

Tripathy, P., Priyadarshini, A., Das, S.K., Sahoo, B.B. and Dash, D.K. (2013). Evaluation of onion (Allium cepa L.) genotypes for tolerance to thrips (Thrips tabaci L.) and purple blotch [Alternaria porri (Ellis) Ciferri]. International Journal of Bio-resource and Stress Management, 4 (4):561- 564.

\section{How to cite this article:}

Nishith Gupta, K. S. Bhargav and Dixit, A. K. 2020. Evaluation of Kharif Onion (Allium cepa L.) Varieties in Malwa Agro Climatic Zone of Madhya Pradesh. Int.J.Curr.Microbiol.App.Sci. 9(12): 2722-2727. doi: https://doi.org/10.20546/ijcmas.2020.912.323 